\title{
The great Cormorant (Phalacrocorax carbo) at lower lake Constance/Germany: dietary composition and impact on commercial fisheries
}

\author{
J. Gaye-Siessegger ${ }^{(1), \star}$
}

Received January 23, 2014

Revised March 19, 2014

Accepted March 24, 2014

\section{ABSTRACT}

Key-words: $\quad$ At lower lake Constance, the number of cormorants (Phalacrocorax carbo) cormorants' diet, has greatly increased during the last 15 years. An investigation of their fisheries yield, hard parts, stomach content analysis

diet can help to estimate the impact on fish and fisheries. Therefore, 282 cormorants were collected for stomach content analysis in autumn/winter 2011/12 and 2012/13. A total of 4019 fish or hard parts of 16 species were identified in the diet of cormorants. Fish length and weight were reconstructed from dimensions of hard parts using regression equations. Perch was the most frequent species (composition by number $=41.5 \%$ ). Based on composition by weight, the most important species in the diet of cormorants was tench (Tinca tinca) with $47.0 \%$, followed by Northern pike (Esox lucius), perch (Perca fluviatilis) and European whitefish (Coregonus lavaretus) with $23.9 \%, 7.2 \%$ and $6.9 \%$, respectively. The dietary composition significantly differed between autumn and winter. Fish of high commercial value played a considerable part in the cormorants' diet. The impact of cormorants on grayling (Thymallus thymallus) could not be assessed due to the low number of birds from the spawning grounds of grayling at the outlet of lower lake Constance.

\section{RÉSUMÉ}

Le grand Cormoran (Phalacrocorax carbo) au lac inférieur de Constance/Allemagne : composition du régime alimentaire et impact sur la pêche commerciale

Mots-clés : alimentation du cormoran, pêche, parties osseuses, analyse du contenu stomacal

\begin{abstract}
Au lac inférieur de Constance, le nombre de cormorans (Phalacrocorax carbo) a fortement augmenté au cours des 15 dernières années. Une étude de leur régime alimentaire peut aider à estimer l'impact sur les poissons et la pêcherie. Par conséquent, 282 cormorans ont été prélevés pour l'analyse du contenu de l'estomac à l'automne/hiver 2011/12 et 2012/13. Un total de 4019 poissons ou de parties dures de 16 espèces ont été identifiées dans le régime alimentaire des cormorans. La longueur du poisson et le poids ont été estimés à partir des dimensions de parties dures en utilisant des équations de régression. La perche était l'espèce la plus fréquente (composition en nombre $=41,5 \%$ ). Basé sur la composition en poids, les espèces les plus importantes dans le régime alimentaire des cormorans ont été la tanche (Tinca Tinca) avec 47,0\%, suivi par le brochet (Esox lucius), la perche (Perca fluviatilis) et le corégone (Coregonus lavaretus) avec 23,9 \%, 7,2 \% et $6,9 \%$, respectivement. La composition du régime alimentaire diffère significativement entre l'automne et l'hiver. Les poissons à haute valeur commerciale tiennent une place considérable dans le régime alimentaire des cormorans. L'impact des cormorans sur les ombres (Thymallus thymallus) n'a pas pu être évalué en raison du faible nombre d'oiseaux provenant des zones de frai de l'ombre à la sortie du lac inférieur de Constance.
\end{abstract}




\section{INTRODUCTION}

The population of Great Cormorant (Phalacrocorax carbo) in Europe has greatly increased during the last 30 years (European Commission, 2013). In particular, the number of the continental subspecies $P$. carbo sinensis has increased dramatically and moved into previously unoccupied areas (Carss and Marzano, 2005). Now cormorants are more numerous across Europe than ever before. Carss and Marzano (2005) assumed that this increase can be attributed to European legislation (Birds Directive, 2009) as well as to a 'non-limiting food supply'. On the other hand, several fish species have declined in abundance and distribution. Many factors are reported to be responsible, such as habitat degradation, environmental changes and invasive species, as well as predation (e.g. Uiblein et al., 2001; Stenseth, et al., 2002; Smokorowski and Pratt, 2007; Hermoso et al., 2011; Almodóvar et al., 2012). Guthörl (2006) supposed that the increased number of cormorants affects fish populations strongly and that local populations of some species are at risk, e.g. grayling (Thymallus thymallus) and barbel (Barbus barbus). While the effect of cormorants on aquaculture facilities is not the subject of discussion, demonstrating their impact on large rivers or other water bodies is difficult because of ecological complexities (Carss and Marzano, 2005). Čech and Vejrík (2011) investigated the impact of cormorants on fish stocks of the River Vltava, Czech Republic. They summarised that most probably cormorants and anglers are responsible for the decline in catches of brown trout (Salmo trutta) and grayling. A good knowledge of the dietary composition of cormorants can help to assess their influence on fisheries and fish species in affected water bodies.

In recent years, the number of cormorants in the federal state Baden-Württemberg/Germany during winter amounted to a total of 10000 birds (Landtag Baden-Württemberg, 2010). The first breeding in Baden-Württemberg was observed in Karlsruhe-Maxau in 1994. Since then the number of breeding pairs rose to 863 in 2012, with the two largest colonies situated at Lake Constance (LUBW, 2013).

Professional fishery has a long tradition in Lake Constance. European whitefish (Coregonus lavaretus) and perch (Perca fluviatilis) are commercially the most important fish species. Professional fishermen suspect a substantial effect of the high number of cormorants on the fisheries yield. The aim of the present study was to investigate the food of cormorants at Lower Lake Constance in order to assess the impact of predation on fisheries and fish species. Therefore, cormorants were collected for stomach content analysis in autumn/winter 2011/12 and 2012/13. The total length and weight of fish were measured, and in the case of hard parts, back-calculated in order to summarise the withdrawn biomass and number of fish species eaten by cormorants.

\section{MATERIALS AND METHODS}

\section{> STUDY AREA}

Lake Constance is situated between Austria, Switzerland and Germany, and is one of the largest lakes in Europe. It is divided into the deep Upper Lake and the shallower Lower Lake. Lower Lake Constance itself is divided into the Rheinsee, Zeller See, Gnadensee and Markelfinger Winkel, and covers an area of approximately $63 \mathrm{~km}^{2}$. The German side of Lower Lake Constance is a special protected area (Vogelschutzgebietsverordnung Baden-Württemberg, 2010) and parts of it are nature reserves.

The phosphorus concentration has strongly decreased in all parts of Lower Lake Constance since the maxima in the 1970s (IGKB, 2006). The annual fisheries yield was between approximately $50 \mathrm{t}$ and $150 \mathrm{t}$ from 1910 to 1965 , while it increased to almost $500 \mathrm{t}$ in the $1970 \mathrm{~s}$ (Figure 1) (IGKB, 2011). Over the past years, the yield of the 40 professional fishermen has decreased to below $200 \mathrm{t}$; especially, the yield of perch dropped heavily (maximum: about $180 \mathrm{t}$ in 1985, minimum: $3.2 \mathrm{t}$ in 2005). According to catch statistics, the yield of commercial fishery summed for the period of investigation was $130 \mathrm{t}$. 


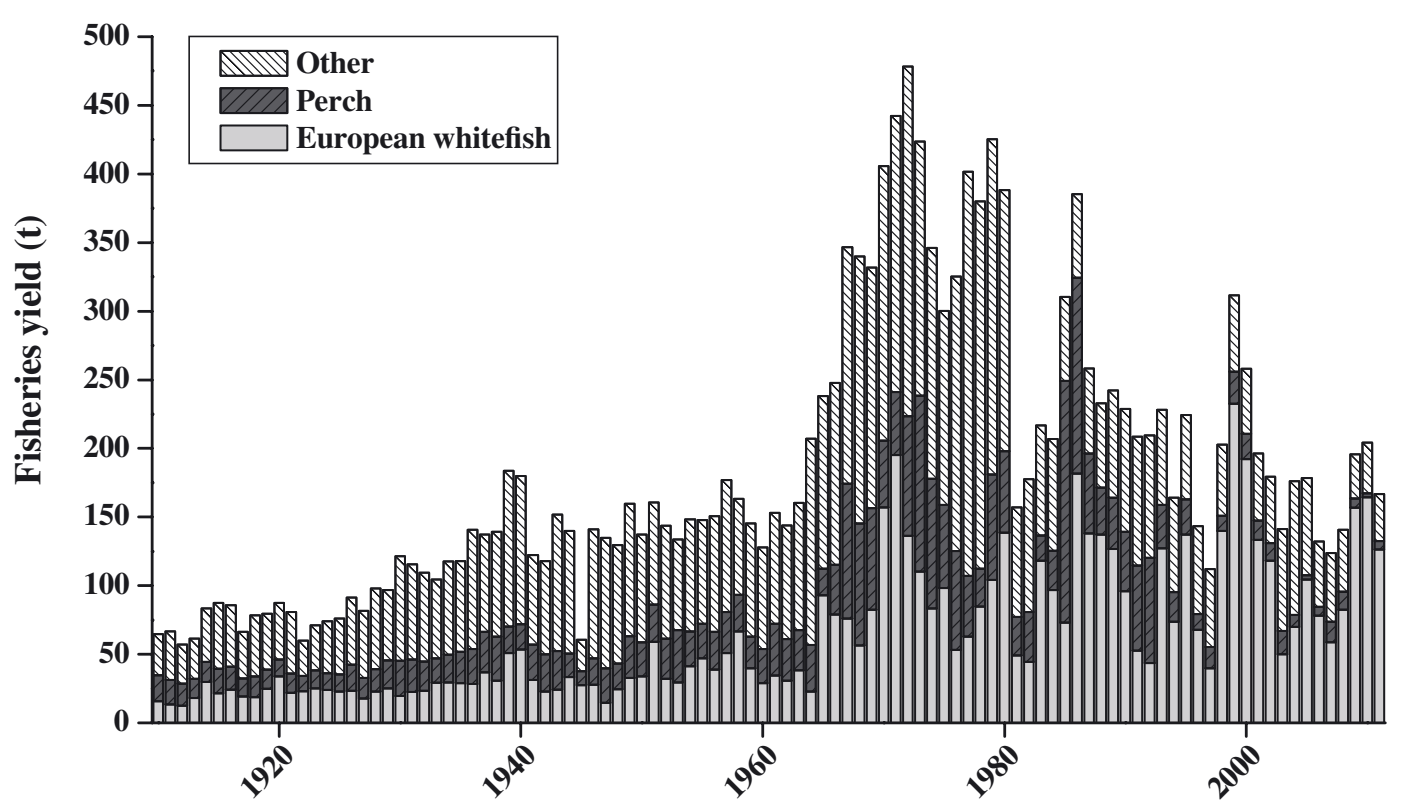

Figure 1

Fisheries yield (metric tons) in Lower Lake Constance from 1910 to 2011 for European whitefish, perch and all other species combined (IGKB, 2011).

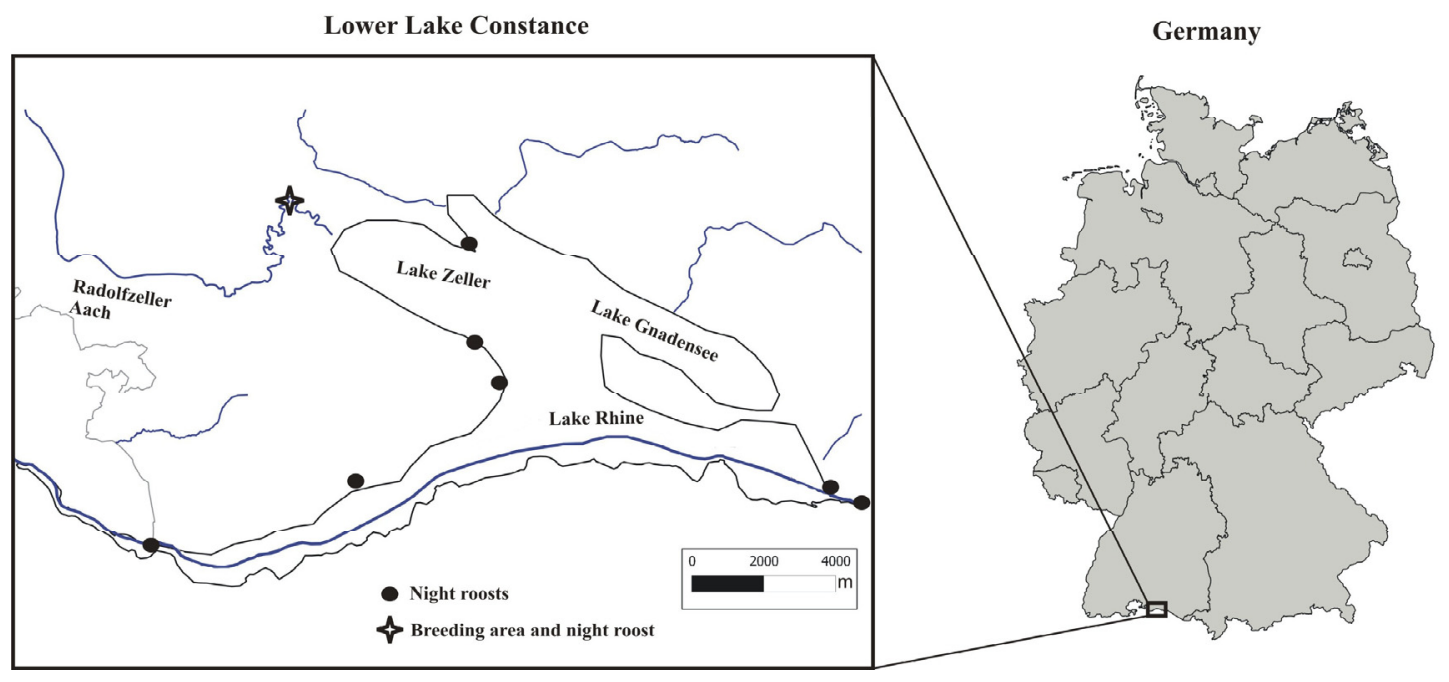

\section{Figure 2}

Night roosts and breeding colony of cormorants at Lower Lake Constance; $\bullet$ night roosts and $\downarrow$ breeding area and night roost.

\section{> CORMORANTS}

The first breeding at Lower Lake Constance was recorded in 1997. From that time on, cormorants have been counted monthly on night roosts in the area of Lower Lake Constance and during the breeding season on nests at the breeding colony Aachmündung (Scheu, 2013). In recent years, night roosts were observed in Aachmündung, Hornspitze, Kuhhorn, Marbach, Mettnau, Langenrain, Werd-Stiegen and Gundholzen (Figure 2). In 2011 and 2012, two breeding colonies were situated at Lake Constance, one at Lower Lake in Aachmündung and the other at Upper Lake in Eriskircher Ried (LUBW, 2013). For more than ten years, it has been permitted to shoot cormorants from 1 September to 15 March in certain areas of Lower Lake Constance in order to prevent serious damage to the professional fisheries 


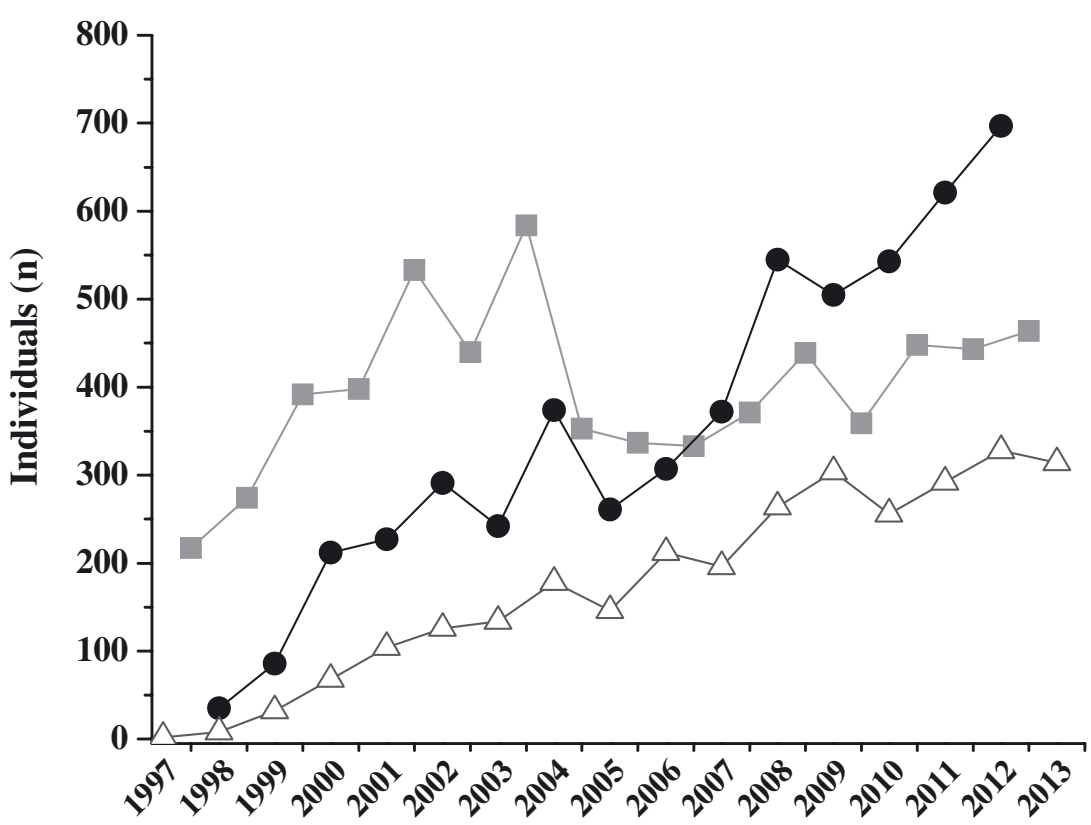

Figure 3

The number of cormorants present at the Lower Lake Constance during autumn/winter (average of monthly counts on night roosts) and summer as well as the development of breeding birds (Scheu, 2013); - - autumn/winter (September-February), - - summer (April-July) and $\backsim$ breeding birds.

as well as to protect the endangered grayling. At the outlet of Lower Lake Constance near Öhningen-Stiegen, shooting is allowed until 15th April.

The average number of cormorants present in the area of Lower Lake Constance during autumn/winter was highest in 2003/04 and was about 400 birds in recent years (Figure 3). Since 1997, the number of breeding pairs rose from 1 to 157 in 2013. During summer, the average number of birds increased from 78 in 1998 to 697 in 2012. On average, 466 (SD: \pm 91 ) cormorants were present in the area of Lower Lake Constance during the study period from October 2011 to April 2012 and from September 2012 to March 2013 (Scheu, 2013). The withdrawal of fish during the period of investigation was calculated as monthly counting of cormorants $\times$ days $\times 397 \mathrm{~g}$ fish per day (Čech and Vejrík, 2011).

\section{> STOMACH CONTENT ANALYSIS}

All cormorants were shot at Lower Lake Constance from October 2011 to April 2012 and from September 2012 to March 2013, and deep-frozen immediately. After defrosting, the birds were weighed, and the stomachs were dissected and weighed as well. Their sex was determined. After opening of the stomach, whole fish (and parts of them) were identified and if possible measured and weighed. The remaining content was rinsed in a sieve (mesh size $0.16 \mathrm{~cm}$ ) and dried in a cup. Hard parts (Figure 4) were used to identify individuals down to the lowest possible taxon by using an existing collection of hard parts of several species as well as identification keys (e.g. März, 1987; Veldkamp, 1995). Based on hard parts, the length and weight of fish were back-calculated using regression equations (Appendix 1). Erosion of hard parts was not taken into account.

The relative importance of a fish species as a food source was assessed by 1) the number of individuals of each species in stomachs (composition by number), and 2) the weight (composition by weight), as well as 3 ) the number of stomachs containing one or more individuals of each fish species (frequency of occurrence; Hyslop, 1980). 

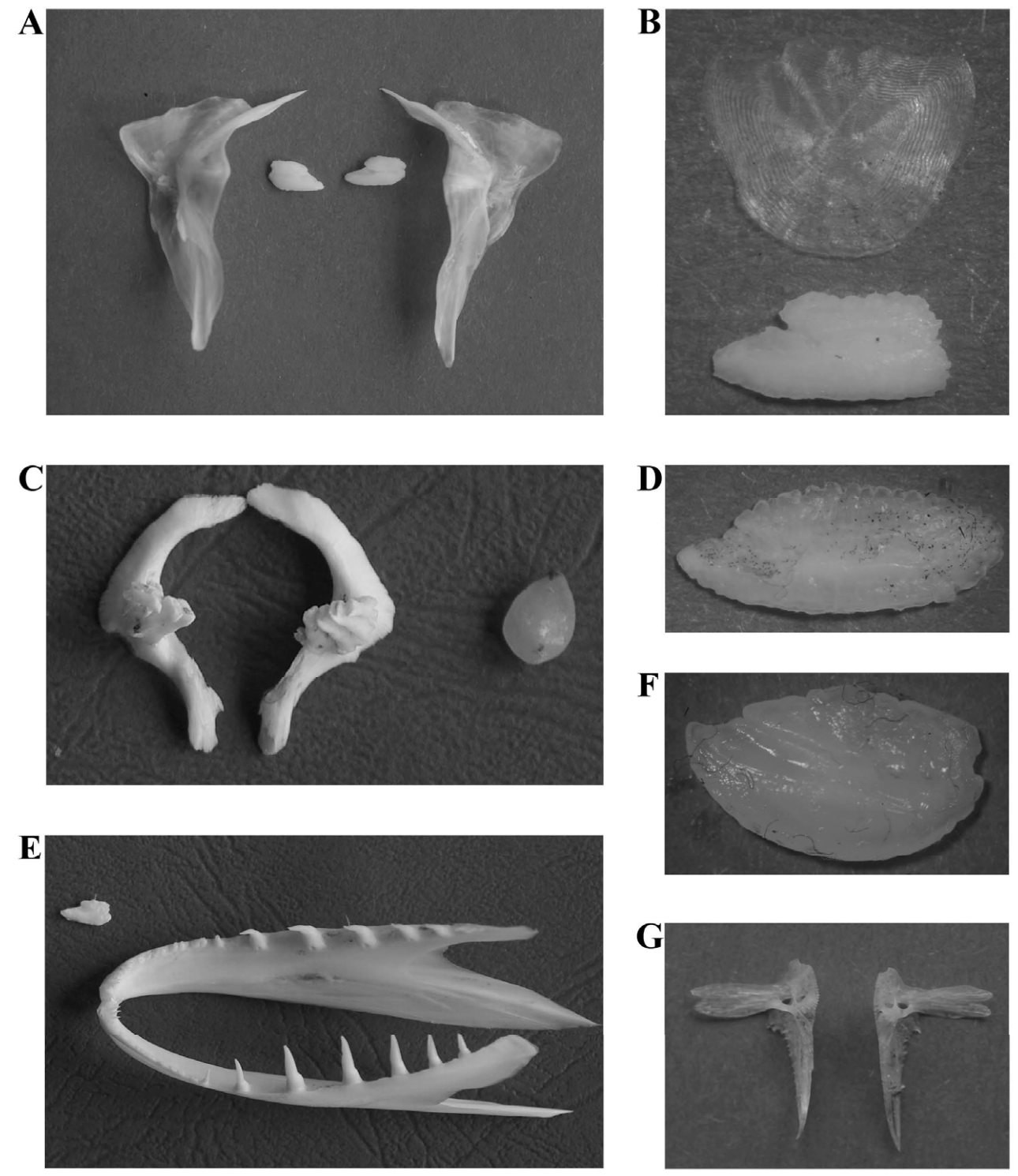

\section{Figure 4}

Examples of hard part used for the identification of fish species: (A) cleithrum and sagittal otolith of European whitefish, (B) scale and sagittal otolith of grayling, (C) pharyngeal bones and chewing pad of tench, (D) sagittal otolith of pikeperch, (E) sagittal otolith and lower jaw of Northern pike, (F) sagittal otolith of ruffe and (G) pelvic bones of three-spined stickleback.

\section{> STATISTICAL ANALYSIS}

Differences in body weight between the sexes were tested using the non-parametric MannWhitney $U$ test. The software used was JMP Version 7.1 (SAS Institute Inc., Cary, NC, USA). The dietary composition of cormorants (based on composition by number and weight) was compared between seasons (Autumn 1: Oct.-Dec. 2011, Winter 1: Jan.-Mar. 2012, Autumn 2: Oct.-Dec. 2012 and Winter 2: Jan.-Mar. 2013) using multivariate analysis of similarity (ANOSIM, Bray-Curtis distance, 9999 permutations) (data from Sep. and Apr. were excluded because they were sampled only in 2012). Fish species primarily responsible for the differences in dietary composition between seasons were subsequently determined by similarity percentages (SIMPER). The software used was PAST Version 2.17 (Hammer et al., 2001). 
Table I

Compositions by number and by weight, and frequency of occurrence of fish species in stomachs of cormorants $(N=282)$.

\begin{tabular}{|c|c|c|c|c|c|c|c|}
\hline \multirow[t]{2}{*}{ Fish species } & \multirow{2}{*}{$\begin{array}{c}\text { Mean } \\
\text { weight }\end{array}$} & \multicolumn{2}{|c|}{$\begin{array}{l}\text { Composition } \\
\text { by number }\end{array}$} & \multicolumn{2}{|c|}{$\begin{array}{l}\text { Composition } \\
\text { by weight }\end{array}$} & \multicolumn{2}{|c|}{$\begin{array}{l}\text { Frequency } \\
\text { of occurence }\end{array}$} \\
\hline & & $(n)$ & $(\%)$ & (g) & $(\%)$ & $(n)$ & $(\%)$ \\
\hline Tench (Tinca tinca) & 146.5 & 253 & 6.3 & 36631 & 47.0 & 130 & 46.1 \\
\hline Northern pike (Esox lucius) & 122.7 & 155 & 3.9 & 18648 & 23.9 & 98 & 34.8 \\
\hline Perch (Perca fluviatilis) & 3.4 & 1666 & 41.5 & 5595 & 7.2 & 87 & 30.9 \\
\hline $\begin{array}{l}\text { European whitefish } \\
\text { (Coregonus lavaretus) }\end{array}$ & 158.5 & 36 & 0.9 & 5388 & 6.9 & 23 & 8.2 \\
\hline Roach (Rutilus rutilus) & 6.1 & 467 & 11.6 & 2872 & 3.7 & 43 & 15.2 \\
\hline Common carp (Cyprinus carpio) & 69.9 & 27 & 0.7 & 1888 & 2.4 & 18 & 6.4 \\
\hline Bream (Abramis brama) & 6.0 & 285 & 7.1 & 1706 & 2.2 & 36 & 12.8 \\
\hline $\begin{array}{l}\text { Three-spined stickleback } \\
\text { (Gasterosteus aculeatus) }\end{array}$ & 1.6 & 978 & 24.3 & 1538 & 2.0 & 54 & 19.1 \\
\hline European eel (Anguilla anguilla) & 218.4 & 5 & 0.1 & 1092 & 1.4 & 5 & 1.8 \\
\hline Pikeperch (Sander lucioperca) & 255.3 & 4 & 0.1 & 1021 & 1.3 & 5 & 1.8 \\
\hline Burbot (Lota lota) & 96.1 & 7 & 0.2 & 673 & 0.9 & 6 & 2.1 \\
\hline Chub (Squalius cephalus) & 45.8 & 6 & 0.1 & 275 & 0.4 & 5 & 1.8 \\
\hline Grayling (Thymallus thymallus) & 236.0 & 1 & 0.02 & 236 & 0.3 & 1 & 0.4 \\
\hline Ruffe (Gymnocephalus cernua) & 11.6 & 19 & 0.5 & 221 & 0.3 & 11 & 3.9 \\
\hline Trout (Salmo trutta) & 86.3 & 1 & 0.02 & 86 & 0.1 & 1 & 0.4 \\
\hline Bleak (Alburnus alburnus) & 14.0 & 3 & 0.1 & 42 & 0.1 & 2 & 0.7 \\
\hline Cyprinidae & & 101 & 2.5 & & & 38 & 13.5 \\
\hline Undefined species & & 5 & 0.1 & & & 5 & 1.8 \\
\hline Crayfish (Orconectes limosus) & & 2 & 0.05 & & & 2 & 0.7 \\
\hline
\end{tabular}

\section{RESULTS}

\section{> DIETARY COMPOSITION OF CORMORANTS}

Stomachs of 282 cormorants (autumn/winter 2011/12: 91 individuals, autumn/winter 2012/13: 191 individuals) were investigated, of which 189 were males, 73 were females and 20 individuals were of unknown sex. The weight (incl. stomach content) ranged between $1706 \mathrm{~g}$ and $4257 \mathrm{~g}$ and differed significantly between the sexes (median (interquartile range): males $2705 \mathrm{~g}$ (2553 to 2901), females $2289 \mathrm{~g}$ (2138 to 2447); Mann-Whitney $U$ test, $P<0.0001$ ). Twenty-seven cormorants had empty stomachs (sixteen males, seven females and four individuals of unknown sex). The 4019 fish or hard parts of them found in stomachs of cormorants were assigned to 16 species (Table I). Species identification was not possible for 101 small cyprinids due to very small hard parts. Therefore, the mass of cyprinids was slightly underestimated. Five fish could not be identified. European eel (Anguilla anguilla) and bleak (Alburnus alburnus) were only found in good condition but no hard parts. The mean weight of threespined stickleback (Gasterosteus aculeatus) found as whole fish in stomachs was used as body weight for each pair of pelvic bones $(1.6 \mathrm{~g})$. The two longest fish were two eels of $64 \mathrm{~cm}$ and $56 \mathrm{~cm}$, and the heaviest fish was a pikeperch (Sander lucioperca) of $804 \mathrm{~g}$. Crayfish Orconectes limosus was found in two stomachs. The population of this alien crayfish in Lower Lake Constance has markedly increased over the past years (personal communication 2014, C. Chucholl).

Fish most frequently fed upon by cormorants were perch (41.5\%), three-spined stickleback (24.3\%) and roach (11.6\%) with 1666, 978 and 467 individuals, respectively (Table I). Based on composition by number, the diet of cormorants significantly differed between Autumn 1 and Winter 1 (ANOSIM: $R=0.1854, P=0.003$ ), Autumn 1 and Autumn 2 (ANOSIM: $R=$ $0.2240, P=0.0006$ ), Autumn 1 and Winter 2 (ANOSIM: $R=0.2482, P=0.0006$ ), Winter 1 


\section{Table II}

Similarity percentage (SIMPER) of the differences in fish composition (by number). The five most important species are shown for comparisons that were significantly different in the ANOSIM.

\begin{tabular}{|c|c|c|c|c|c|c|}
\hline Period 1 & Period 2 & $\begin{array}{c}\text { Average } \\
\text { dissimilarity }\end{array}$ & Species & Contribution (\%) & \begin{tabular}{|l|}
$\mid$ Mean ab \\
Period 1
\end{tabular} & $\begin{array}{l}\text { Undance } \\
\text { Period } 2\end{array}$ \\
\hline \multirow{5}{*}{ Autumn 1} & \multirow{5}{*}{ Winter 1} & \multirow{5}{*}{84.95} & Three-spined stickleback & 36.9 & 14.00 & 2.59 \\
\hline & & & Tench & 16.5 & 0.72 & 1.23 \\
\hline & & & Perch & 12.9 & 3.00 & 0.41 \\
\hline & & & Northern pike & 9.5 & 0.32 & 0.41 \\
\hline & & & European whitefish & 3.1 & 0.20 & 0.07 \\
\hline \multirow{5}{*}{ Autumn 1} & \multirow{5}{*}{ Autumn 2} & \multirow{5}{*}{89.88} & Perch & 24.4 & 3.00 & 18.20 \\
\hline & & & Three-spined stickleback & 23.0 & 14.00 & 0.51 \\
\hline & & & Roach & 16.3 & 0.04 & 7.40 \\
\hline & & & Bream & 11.2 & 0.12 & 4.84 \\
\hline & & & Tench & 7.7 & 0.72 & 0.67 \\
\hline \multirow{5}{*}{ Autumn 1} & \multirow{5}{*}{ Winter 2} & \multirow{5}{*}{84.01} & Three-spined stickleback & 34.9 & 14.00 & 2.05 \\
\hline & & & Tench & 16.4 & 0.72 & 1.25 \\
\hline & & & Perch & 14.2 & 3.00 & 0.72 \\
\hline & & & Northern pike & 11.9 & 0.32 & 0.83 \\
\hline & & & European whitefish & 2.5 & 0.20 & 0.04 \\
\hline \multirow{5}{*}{ Winter 1} & \multirow{5}{*}{ Autumn 2} & \multirow{5}{*}{88.06} & Perch & 26.2 & 0.41 & 18.20 \\
\hline & & & Roach & 20.8 & 0.07 & 7.40 \\
\hline & & & Bream & 14.2 & 0.05 & 4.84 \\
\hline & & & Tench & 13.7 & 1.23 & 0.67 \\
\hline & & & Three-spined stickleback & 9.4 & 2.59 & 0.51 \\
\hline \multirow{5}{*}{ Autumn 2} & \multirow{5}{*}{ Winter 2} & \multirow{5}{*}{87.18} & Perch & 27.0 & 18.20 & 0.72 \\
\hline & & & Roach & 21.0 & 7.40 & 0.45 \\
\hline & & & Bream & 14.1 & 4.84 & 0.11 \\
\hline & & & Tench & 13.6 & 0.67 & 1.25 \\
\hline & & & Northern pike & 9.3 & 0.44 & 0.83 \\
\hline
\end{tabular}

and Autumn 2 (ANOSIM: $R=0.2491, P=0.0006$ ) and Autumn 2 and Winter 2 (ANOSIM: $R=0.2880, P=0.0006$ ). The species that contributed most to the observed differences in cormorants' diet are shown in Table II. Three-spined stickleback was most abundant in the stomachs of cormorants in Autumn 1, while it was perch in Autumn 2. In winter, the number of tench and Northern pike increased greatly.

Based on composition by weight, tench $(47.0 \%)$ was the most important fish species for cormorants, followed by Northern pike (23.9\%), perch (7.2\%) and European whitefish $(6.9 \%)$ (Table I). The dietary composition of cormorants significantly differed between Autumn 1 and Winter 1 (ANOSIM: $R=0.1593, P=0.0024$ ), Autumn 1 and Autumn 2 (ANOSIM: $R=0.1707$, $P=0.0018$ ), Autumn 1 and Winter 2 (ANOSIM: $R=0.2247, P=0.0012$ ), Winter 1 and Autumn 2 (ANOSIM: $R=0.2215, P=0.0006$ ) and Autumn 2 and Winter 2 (ANOSIM: $R=0.2524$, $P=0.0006)$. The species that contributed most to the observed differences in cormorants' diet are shown in Table III. In winter, the diet of cormorants was dominated by tench and Northern pike, while perch, European whitefish and roach played a considerable role in autumn.

Almost half of the cormorants fed on tench (46.1\%), 34.8\% Northern pike and 30.9\% perch (Table I).

\section{DISCUSSION}

Studies on the dietary composition of wild animals are usually complex; in the case of cormorant feeding observations, stomach content analysis and regurgitated pellet analysis are 
Table III

Similarity percentage (SIMPER) of the differences in fish composition (by weight). The five most important species are shown for comparisons that were significantly different in the ANOSIM.

\begin{tabular}{|c|c|c|c|c|c|c|}
\hline Period 1 & Period 2 & $\begin{array}{c}\text { Average } \\
\text { dissimilarity }\end{array}$ & Species & Contribution (\%) & \multicolumn{2}{|c|}{ Mean abundance } \\
\hline \multirow{5}{*}{ Autumn 1} & \multirow{5}{*}{ Winter 1} & \multirow{5}{*}{85.76} & Tench & 36.2 & 54.5 & 182.0 \\
\hline & & & Northern pike & 19.2 & 44.7 & 62.2 \\
\hline & & & European whitefish & 8.3 & 25.0 & 20.7 \\
\hline & & & Three-spined stickleback & 8.2 & 22.0 & 4.2 \\
\hline & & & Perch & 7.9 & 33.9 & 3.7 \\
\hline \multirow{5}{*}{ Autumn 1} & \multirow{5}{*}{ Autumn 2} & \multirow{5}{*}{89.20} & Tench & 19.0 & 54.5 & 77.1 \\
\hline & & & Northern pike & 17.2 & 44.7 & 63.2 \\
\hline & & & Perch & 13.6 & 33.9 & 52.9 \\
\hline & & & European whitefish & 13.0 & 25.0 & 49.6 \\
\hline & & & Roach & 10.1 & 1.5 & 37.9 \\
\hline \multirow{5}{*}{ Autumn 1} & \multirow{5}{*}{ Winter 2} & \multirow{5}{*}{85.74} & Tench & 35.8 & 54.5 & 199.0 \\
\hline & & & Northern pike & 24.4 & 44.7 & 94.6 \\
\hline & & & Three-spined stickleback & 8.0 & 22.0 & 3.2 \\
\hline & & & Perch & 7.7 & 33.9 & 2.6 \\
\hline & & & European whitefish & 5.9 & 25.0 & 4.3 \\
\hline \multirow{5}{*}{ Winter 1} & \multirow{5}{*}{ Autumn 2} & \multirow{5}{*}{87.25} & Tench & 36.0 & 182.0 & 77.1 \\
\hline & & & Northern pike & 18.9 & 62.2 & 63.2 \\
\hline & & & European whitefish & 11.5 & 20.7 & 49.6 \\
\hline & & & Perch & 10.1 & 3.7 & 52.9 \\
\hline & & & Roach & 9.8 & 0.9 & 37.9 \\
\hline \multirow{5}{*}{ Autumn 2} & \multirow{5}{*}{ Winter 2} & \multirow{5}{*}{87.17} & Tench & 35.6 & 77.1 & 199.0 \\
\hline & & & Northern pike & 23.8 & 63.2 & 94.6 \\
\hline & & & Roach & 10.3 & 37.9 & 4.7 \\
\hline & & & Perch & 9.8 & 52.9 & 2.6 \\
\hline & & & European whitefish & 9.4 & 49.6 & 4.3 \\
\hline
\end{tabular}

used (Carss et al., 2012). Attention has to be paid to the fact that otoliths of small fish erode more quickly in the stomachs of birds than otoliths of larger fish, and therefore the backcalculated lengths of small fish are underestimated. In addition, hard parts can derive from stomach contents of ingested piscivorous fish (Blackwell and Sinclair, 1995). A feeding experiment with cormorants in captivity showed that the recovery of eel otoliths in regurgitated pellets is low; only $41 \%$ of the eels fed to the cormorants were found again (Worthmann and Spratte, 1987). Stomachs of cormorants contain intact fish and partly digested fish as well as hard parts. In contrast to pellet analysis, the erosion of hard parts is mostly less advanced. Only intact fish have been determined in some studies on the stomach content of cormorants (Dornbusch and Fischer, 2010; Simon, 2011), but this approach underestimates the proportion of small fish even more. In the present study, fish, fish remains and hard parts were used to identify individuals down to the lowest possible taxon in order to investigate the dietary composition of cormorants at Lower Lake Constance. Based on composition by weight, the most important species in the diet of cormorants were tench, followed by Northern pike, perch and European whitefish. These four commercially important species accounted for $85 \%$ of the cormorants' diet. Most birds were shot in the morning so that the mass of fish found in stomachs did not represent the entire daily food ration. Almost half of the cormorants ingested tench and one-third Northern pike and perch, respectively. More than $40 \%$ of the individual fish found in stomachs were perch. Most of these fish were fed on in autumn. In Lake Constance, perch leave the littoral in autumn and move to deeper waters for overwintering (Wang and Eckmann, 1994; Eckmann and Imbrock, 1996). The removal of a high number of small perch by cormorants may negatively influence the recruitment of perch and thus reduce 
professional fisheries' yield. A high number of three-spined sticklebacks were ingested as well, but based on fish biomass this species was of minor importance. In accordance with the results of other studies, the species composition of cormorants' diet varied considerably with the season (Čech et al., 2008; Emmrich and Düttmann, 2011).

Results of other studies on the diet of cormorants differ depending on many factors, such as the type of water body where the cormorants fed and the sample period, as well as the method applied. Klein and Lieser (2005) investigated the dietary composition of cormorants based on the analysis of 143 pellets collected under roost trees in Radolfzeller Aachried in winter 2004/05. They assumed that the fish consumed by the cormorants originated from the Zeller See, which is the westernmost part of Lower Lake Constance, but they could not exclude that cormorants fed at other water bodies too. Although the distances between night roosts and foraging sites are generally only a few kilometres, the distance can be up to 30-40 km (Carss et al., 2012). In the present study, cormorants were shot during their feeding at the Lower Lake. Klein and Lieser (2005) found remains of 567 fish, which were assigned to 17 species, and expressed their results as percentage composition by number. In contrast to the present study, which was conducted in the same area and also during autumn/winter but some years later, cyprinids comprised $40.6 \%$ of the cormorants' diet, of which $19.6 \%$ were undetermined cyprinids. Northern pike accounted for $15.0 \%$ and perch for $12.7 \%$. These data differ considerably from the data in the corresponding column of Table I. Although three-spined stickleback was the second most numerous species in the present study, Klein and Lieser (2005) did not find a single individual due to pellet analysis. The difference in the numbers of carp ingested may be due to the fact that in 2003, natural reproduction of carp was very successful and an abundant population was in the lake in the subsequent years (Roesch, 2008). According to Klein and Lieser (2005), the endangered grayling had a proportion of $1.6 \%$; in the present study, this species was only found once. At the outlet of Lower Lake Constance, near Öhningen, grayling spawn in April. While the investigation of Klein and Lieser (2005) ended in March, a few cormorants from April were examined in the present study. In summer 2003 , mortality of grayling was high because of the water temperature exceeding the upper tolerance limit of grayling, and since then the population has only recovered slightly. It would be necessary to investigate stomach contents throughout the year in order to assess the total impact of cormorants at Lower Lake Constance on the fish community.

Suter (1997) evaluated data from Lower Lake Constance collected between 1974 and 1984. He found 2001 fish in 914 pellets and expressed the results as composition by number and frequency of occurrence. Perch was the most numerous species with $28.8 \%$, followed by grayling (13.8\%), tench (11.8\%), roach (10.7\%) and undetermined cyprinids (10.1\%). About $20 \%$ of cormorants fed on grayling, $13.3 \%$ European whitefish, $12.6 \%$ tench and $11.4 \%$ perch. These data are difficult to compare with the results of the present study, as the exact sampling period is not defined and during the 1970s the nutrient status of Lower Lake Constance was at its highest level and since then has decreased significantly (IGKB, 2006). The professional fisheries yield as well as the relative species composition in the catch has changed (Roesch, 2008).

Cowx (2013) stated that there is a deficit of detailed studies which would help to define the impact and there are no precise guidelines or criteria which help to assess the scale of damage to fish stocks and fisheries. The present study identified the dietary composition of cormorants at Lower Lake Constance in autumn/winter 2011/12 and 2012/13. Ridgway (2010) reviewed the recent literature on the daily food intake (DFI) of cormorants (Phalacrocorax spp.) and recommended a consumption of $436 \mathrm{~g} \cdot \mathrm{d}^{-1}$ in the non-nesting season. Čech and Vejrík (2011) calculated the DFI of $P$. carbo sinensis as an average of the results of different methods, time-energy budget, doubly-labelled water, and stomach and pellet analysis as well as direct

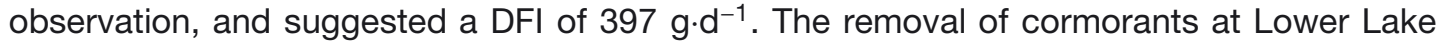
Constance was at least 80 t during the study period. Cormorants' consumption reached a minimum of $60 \%$ of the yield of commercial fishery and thus strong competition between cormorants and professional fishermen is suggested. However, as professional fishermen are 
allowed to repel cormorants during autumn and winter, damage to gill nets and to European whitefish caught in the nets could be clearly reduced in recent years while other species such as tench, Northern pike and perch were caught in large quantities. In autumn, a great number of small perch were removed by cormorants. The influence of cormorants in reality is much higher than the amount of perch ingested, as most of the fish are below the allowed minimum size. In addition, fish injured by cormorants cause indirect losses (Grémillet et al., 2006; Kortan et al., 2008). The wounds are ports of entry for fish pathogens which can result in subsequent infection and mortality.

Fish distribution (horizontal as well as vertical) is clearly different between summer and winter and hence, the 'availability' of fish to cormorants. During summer, when the cormorant population actually is highest, fish are distributed more in shallow areas, which make them more vulnerable to cormorant predation. The present regulations allow shooting of cormorants from September to March (April), that is, in the time period when the fish are found more in deeper areas. The present study covers the autumn and winter situation. It is unknown whether cormorants' fish prey in spring and summer is similar to the prey in autumn and winter. For a complete picture of the diet of cormorants and their impact on fisheries and fish species, stomach contents should be analysed the whole year round, particularly with regard to the endangered grayling.

\section{ACKNOWLEDGEMENTS}

This project was funded by the Fischereiabgabe Baden-Wuerttemberg. The author would like to thank W. Scheu and the Landesfischereiverband Baden e.V. for their cormorant counts at Lower Lake Constance since 1997 as well as S. Riebel and colleagues for the collection of cormorants. Special thanks go to R. Roesch for comments on previous drafts of this manuscript.

\section{REFERENCES}

Almodóvar A., Nicola G.G., Ayllón D. and Elvira B., 2012. Global warming threatens the persistence of Mediterranean brown trout. Glob. Chang. Biol., 18, 1549-1560.

Becke C., 2012. Altersstruktur und Nahrungsspektrum der Trüsche (Lota lota) im oligotrophen Bodensee. Master thesis, Muenster: University of Muenster, Germany, $85 \mathrm{p}$.

Birds Directive, 2009. Directive 2009/147/EC of the European Parliament and of the Council of 30 November 2009 on the conservation of wild birds. Official J. Eur. Union, L 20, 7-25.

Blackwell B.F. and Sinclair J.A., 1995. Evidence of secondary consumption of fish by double-crested cormorants. Mar. Ecol. Progr. Ser., 123, 1-4.

Carss D.N. and Marzano M., 2005. Reducing the conflict between cormorants and fisheries on a panEuropean scale. Redcafe - Summary and National Overviews, $374 \mathrm{p}$.

Carss D.N., Parz-Gollner R. and Trauttmansdorff J., 2012. The INTERCAFE Field Manual: research methods for cormorants, fishes, and the interactions between them. INTERCAFE COST Action 635 Final Report II (ISBN 978-1-906698-08-9), 141 p.

Čech M. and Vejŕík L., 2011. Winter diet of great cormorant (Phalacrocorax carbo) on the River Vitava: estimate of size and species composition and potential for fish stock losses. Folia Zoologica, 60, 129-142.

Čech M., Čech P., Kubečka J., Prchalová M. and Draštík V., 2008. Size Selectivity in Summer and Winter Diets of Great Cormorant (Phalacrocorax carbo): Does it Reflect Season-Dependent Difference in Foraging Efficiency? Waterbirds, 31, 438-447.

Cowx I.G., 2013. Between Fisheries and Bird Conservation: The Cormorant Conflict. Note, DirectorateGeneral for Internal Policies, Policy Department B: Structural and Cohesion Policies, Fisheries, $62 \mathrm{p}$.

Dornbusch G. and Fischer S., 2010. Nahrungsuntersuchungen an Kormoranen in Sachsen-Anhalt. Naturschutz im Land Sachsen-Anhalt, 1 + 2, 16-25.

Eckmann R. and Imbrock F., 1996. Distribution and diel vertical migration of Eurasian perch (Perca fluviatilis L.) during winter. Annales Zoologici Fennici, 33, 679-686. 
Emmrich M. and Düttmann H., 2011. Seasonal shifts in diet composition of Great Cormorants Phalacrocorax carbo sinensis foraging at a shallow eutrophic inland lake. Ardea, 99, 207-217.

European Commission, 2013. Great cormorant - Applying derogations under Article 9 of the Birds Directive 2009/147/EC. Luxembourg: Publications Office of the European Union, 22 p.

Grémillet D., Enstipp M.R., Boudiffa M. and Liu H., 2006. Do cormorants injure fish without eating them? An underwater video study. Marine Biology, 148, 1081-1087.

Guthörl V., 2006. Zum Einfluss des Kormorans (Phalacrocorax carbo) auf Fischbestände und aquatische Ökosysteme - Fakten, Konflikte und Perspektiven für kulturlandschaftsgerechte Wildhaltung. 2nd updated ed., Rolbing: Wildland Weltweit Verlag, 254 p.

Hammer Ø., Harper D.A.T., Ryan P.D., 2001. PAST: Paleontological statistics software package for education and data analysis. Palaeontologia Electronica, 4, 9 p.

Hermoso V., Clavero M., Blanco-Garrido F. and Prenda J., 2011. Invasive species and habitat degradation in Iberian streams: an analysis of their role in freshwater fish diversity loss. Ecol. Appl., 21, 175-188.

Hyslop E.J., 1980. Stomach contents analysis: a review of methods and their application. J. Fish Biol., $17,411-429$.

IGKB, 2006. Zur limnologischen Entwicklung des Bodensee-Untersees von 1969-2005. Report of the "Internationale Gewässerschutzkommission für den Bodensee", 57, 17 p., www.igkb.de.

IGKB, 2011. Limnologischer Zustand des Bodensees. Report of the "Internationale Gewässerschutzkommission für den Bodensee", 39, 95 p., www.igkb.de.

Klein B. and Lieser M., 2005. Zum Beutespektrum des Kormorans Phalacrocorax carbo am westlichen Bodensee. Vogelwarte, 43, 267-270.

Kortan J., Adámek Z., Flajšhans M. and Piačková V., 2008. Indirect manifestation of cormorant (Phalacrocorax carbo sinensis (L.)) predation on pond fish stock. Knowl. Manag. Aquatic Ecosyst., 389, 01.

Landtag Baden-Württemberg, 2010. Schutz der heimischen Fischbestände vor Kormoranen. Drucksache 14/6089, www.landtag-bw.de/.

LUBW, 2013. Der Kormoran (Phalacrocorax carbo) in Baden-Württemberg - Landesweite Brutbestandserfassung 2012. Report of the "Landesanstalt für Umwelt, Messungen und Naturschutz Baden-Württemberg", www.lubw.baden-wuerttemberg.de/servlet/is/212964/.

März R., 1987. Gewöll- und Rupfungskunde. 3. Auflage, Aula-Verlag, Wiebelsheim, 398 p.

Ridgway M.S., 2010. A review of estimates of daily energy expenditure and food intake in cormorants (Phalacrocorax spp.). J. Great Lakes Res., 36, 93-99.

Roesch R., 2008. Langzeitentwicklung der Fischerträge im Bodensee-Untersee Teil 1: Felchen, Barsch, Karpfen, Brachsen und Sonstige Weißfische. Aquakultur- und Fischereiinformationen, 3, 3-6.

Scheu W., 2013. Monthly counts on behalf of the Landesfischereiverband Baden e.V. www.lfvbaden.de/.

Simon J., 2011. Wenn Jäger zu Gejagten werden - Nahrungsuntersuchungen an Kormoranen in der Havel bei Potsdam. Fischer \& Teichwirt, 1, 6-9.

Smokorowski K.E. and Pratt T.C., 2007. Effect of a change in physical structure and cover on fish and fish habitat in freshwater ecosystems - a review and meta-analysis. Environ. Rev., 15, 15-41.

Stenseth N.C., Mysterud A., Ottersen G., Hurrell J.W., Chan K.-S. and Lima M., 2002. Ecological Effects of Climate Fluctuations. Science, 297, 1292-1296.

Suter W., 1997. Roach rules: shoaling fish are a constant factor in the diet of cormorants Phalacrocorax carbo in Switzerland. Ardea, 85, 9-27.

Uiblein F., Jagsch A., Honsig-Erlenburg W. and Weiss S., 2001. Status, habitat use, and vulnerability of the European grayling in Austrian waters. J. Fish Biol., 59, 223-247.

Veldkamp R., 1995. The use of chewing pads for estimating the consumption of cyprinids by cormorants. Ardea, 83, 135-138.

Vogelschutzgebietsverordnung Baden-Württemberg, 2010. Verordnung des Ministeriums für Ernährung und Ländlichen Raum zur Festlegung von Europäischen Vogelschutzgebieten (VSG-VO). Gesetzblatt für Baden-Württemberg, 3, 37-263.

Wang N. and Eckmann R., 1994. Distribution of perch (Perca fluviatilis L.) during their first year of life in Lake Constance. Hydrobiologia, 277, 135-143.

Worthmann H. and Spratte S., 1987. Nahrungsuntersuchungen am Kormoran (Phalacrocorax carbo) Die Auswirkungen der Kormorane auf die schleswig-holsteinische Binnenfischerei. SchleswigHolstein, Fischereiamt, 208 p. 


\section{APPENDIX 1}

Regression equations for back-calculation of length and weight of fish.

\begin{tabular}{|c|c|c|c|c|}
\hline Species & Regression & $R^{2}$ & $n$ & Literature* \\
\hline Bleak (Alburnus alburnus) & $B W=0.0070^{*} T^{3.0068}$ & 0.99 & 653 & \\
\hline Bream (Abramis brama) & $\begin{array}{l}\mathrm{BW}=0.0102^{*} \mathrm{TL}^{2.9710} \\
\mathrm{TL}=1.6951^{*} \mathrm{PhT}+0.1201\end{array}$ & $\begin{array}{l}0.99 \\
0.99\end{array}$ & $\begin{array}{l}76 \\
27\end{array}$ & Emmrich \& Düttmann 2011 \\
\hline Burbot (Lota lota) & $\begin{array}{l}B W=0.0049^{*} T^{3.1183} \\
T L=4.632^{*} S-3.6891\end{array}$ & $\begin{array}{l}0.97 \\
0.89\end{array}$ & $\begin{array}{l}607 \\
437\end{array}$ & $\begin{array}{l}\text { Becke } 2012 \\
\text { Becke } 2012\end{array}$ \\
\hline Chub (Squalius cephalus) & $\begin{array}{l}\mathrm{BW}=0.0096^{\star} \mathrm{TL}^{3.0237} \\
\mathrm{TL}=1.3733^{\star} \mathrm{PhT}-0.025\end{array}$ & $\begin{array}{l}0.99 \\
0.99\end{array}$ & $\begin{array}{c}1114 \\
83\end{array}$ & Čech et al. 2008 \\
\hline $\begin{array}{l}\text { Common carp } \\
\text { (Cyprinus carpio) }\end{array}$ & $\begin{array}{l}\mathrm{BW}=0.0130^{*} \mathrm{TL}^{3.0968} \\
\mathrm{TL}=1.1102^{*} \mathrm{PhT}-2.8219\end{array}$ & $\begin{array}{l}0.99 \\
0.99\end{array}$ & $\begin{array}{l}69 \\
13\end{array}$ & Čech et al. 2008 \\
\hline $\begin{array}{l}\text { European whitefish } \\
\text { (Coregonus lavaretus) }\end{array}$ & $\begin{array}{l}\mathrm{BW}=0.0267^{\star} \mathrm{TL}^{2.6162} \\
\mathrm{TL}=4.1086^{\star} \mathrm{S}+0.9976\end{array}$ & $\begin{array}{l}0.96 \\
0.95\end{array}$ & $\begin{array}{l}53 \\
21\end{array}$ & \\
\hline $\begin{array}{l}\text { Grayling } \\
\text { (Thymallus thymallus) }\end{array}$ & $B W=0.0060^{\star} T L^{3.1106}$ & 0.99 & 143 & \\
\hline $\begin{array}{l}\text { Northern pike } \\
\text { (Esox lucius) }\end{array}$ & $\begin{array}{l}\mathrm{BW}=0.0021^{*} \mathrm{~T} L^{3.2851} \\
\mathrm{TL}=0.6981^{*} \mathrm{DeL}+3.9125 \\
\mathrm{TL}=7.2847^{\star} \mathrm{S}-7.6369\end{array}$ & $\begin{array}{l}0.98 \\
0.99 \\
0.91\end{array}$ & $\begin{array}{c}17 \\
7 \\
18\end{array}$ & Čech et al. 2008 \\
\hline Perch (Perca fluviatilis) & $\begin{array}{l}\mathrm{BW}=0.0105^{\star} \mathrm{TL}^{2.9872} \\
\mathrm{TL}=3.8436^{\star} \mathrm{S}-3.7800 \\
\mathrm{TL}=0.8824^{\star} \mathrm{PO}+0.5559\end{array}$ & $\begin{array}{l}0.98 \\
0.94 \\
0.98\end{array}$ & $\begin{array}{c}1146 \\
47 \\
47\end{array}$ & $\begin{array}{l}\text { Emmrich \& Düttmann } 2011 \\
\text { Emmrich \& Düttmann } 2011\end{array}$ \\
\hline $\begin{array}{l}\text { Pikeperch } \\
\text { (Sander lucioperca) }\end{array}$ & $\begin{array}{l}\mathrm{BW}=0.0040^{*} \mathrm{TL}^{3.1758} \\
\mathrm{TL}=4.6879^{*} \mathrm{~S}-4.6704 \\
\mathrm{TL}=0.8732^{*} \mathrm{PO}+0.6564\end{array}$ & $\begin{array}{l}0.98 \\
0.93 \\
0.96\end{array}$ & $\begin{array}{l}59 \\
59 \\
59\end{array}$ & $\begin{array}{l}\text { Emmrich \& Düttmann } 2011 \\
\text { Emmrich \& Düttmann } 2011 \\
\text { Emmrich \& Düttmann } 2011\end{array}$ \\
\hline Roach (Rutilus rutilus) & $\begin{array}{l}\mathrm{BW}=0.0062^{\star} \mathrm{TL}^{3.2326} \\
\mathrm{TL}=1.6603^{\star} \mathrm{PhT}+0.3244\end{array}$ & $\begin{array}{l}0.99 \\
0.99\end{array}$ & $\begin{array}{c}284 \\
46\end{array}$ & Emmrich \& Düttmann 2011 \\
\hline $\begin{array}{l}\text { Ruffe } \\
\text { (Gymnocephalus cernua) }\end{array}$ & $\begin{array}{l}\mathrm{BW}=0.0117^{\star} \mathrm{TL}^{3.0442} \\
\mathrm{TL}=2.2696^{\star} \mathrm{S}-0.0459 \\
\mathrm{TL}=0.9482^{*} \mathrm{PO}-0.2658\end{array}$ & $\begin{array}{l}0.98 \\
0.97 \\
0.98\end{array}$ & $\begin{array}{l}637 \\
64 \\
64\end{array}$ & $\begin{array}{l}\text { Emmrich \& Düttmann } 2011 \\
\text { Emmrich \& Düttmann } 2011\end{array}$ \\
\hline $\begin{array}{l}\text { Tench (Tinca tinca) } \\
\text { Trout (Salmo trutta) }\end{array}$ & $\begin{array}{l}\mathrm{BW}=0.0088^{\star} \mathrm{TL}^{3.1628} \\
\mathrm{TL}=1.3323^{\star} \mathrm{PhT}-0.2690 \\
\mathrm{BW}=0.0105^{\star} \mathrm{TL}^{3.0091}\end{array}$ & $\begin{array}{l}0.99 \\
0.99 \\
0.99\end{array}$ & $\begin{array}{l}50 \\
18 \\
33\end{array}$ & Emmrich \& Düttmann 2011 \\
\hline
\end{tabular}

* Own data were used for regressions when fields are blank BW = body weight $(\mathrm{g}), \mathrm{TL}=$ total length $(\mathrm{cm}), \mathrm{PhT}=$ tip of pharyngeal bone $(\mathrm{mm}), \mathrm{S}=$ length of sagittal otolith $(\mathrm{mm}), \mathrm{DeL}=$ length of dentale $(\mathrm{mm}), \mathrm{PO}=$ diagonal of preoperculum $(\mathrm{mm})$. 